\title{
Klasifikasi Teks Pengaduan Masyarakat Dengan Menggunakan Algoritma Neural Network
}

\author{
Dyan Yuliana $^{1}$, Purwanto ${ }^{2}$, Catur Supriyanto ${ }^{3}$ \\ STKIP PGRI Situbondo \\ pitikpitik23@gmail.com
}

\begin{abstract}
Abstrak
Perkembangan internet menyebabkan membanjirnya informasi digital. Berbagai informasi bisa didapatkan dengan mudah yaitu hanya dengan meng-klik atau menekan 'enter'. Penyebaran informasi dalam bentuk dokumen digital telah mengalami pertumbuhan yang sangat pesat. Salah satu web yang diperuntukkan bagi masyarakat umum di provinsi Jawa Tengah yaitu web yang bernama 'Lapor Gub !'. Web ini dibuat dengan tujuan untuk menampung aspirasi, keluhan, maupun pengaduan masyarakat terhadap pelayanan publik dan juga ketidakpuasan terhadap kinerja pemerintah daerah maupun pemerintah provinsi Jawa Tengah. Peningkatan jumlah dokumen dalam format teks yang cukup signifikan belakangan ini membuat proses pengelompokan dokumen (document classification) menjadi penting. Dengan menggunakan metode klasifikasi teks, maka kumpulan dokumen yang jumlahnya sangat besar tersebut diorganisir sedemikian rupa sehingga dapat mempermudah dan mempercepat pencarian informasi yang dibutuhkan. Eksperimen pada penelitian ini ditujukan untuk mengklasifikasikan dokumen teks berbahasa Indonesia dengan menggunakan algoritma Neural Network. Uji coba dilakukan dengan menggunakan sampel dokumen teks yang diambil dari sebuah media massa elektronik berbasis web yang berjudul 'Lapor Gub !'. Hasil eksperimen menunjukkan bahwa metode Neural Network efektif digunakan untuk mengklasifikasikan teks pengaduan masyarakat. Hal ini terlihat dari hasil eksperimen, yaitu penggunaan algoritma Neural Network pada proses klasifikasi menghasilkan akurasi yang tinggi yaitu sebesar 43,00\% dengan jangka waktu 03 jam 45 menit 14 detik dalam mengklasifikasikan dokumen teks berbahasa Indonesia pada teks pengaduan masyarakat.
\end{abstract}

Kata kunci : Klasifikasi, Neural Network, Pengaduan Masyarakat.

\begin{abstract}
The development of the Internet led to a flood of digital information. Various information can be obtained easily just by clicking or pressing 'enter'. Dissemination of information in the form of digital documents has experienced unprecedented growth. One of the web intended for the general public in the province of Central Java, web named 'Lapor Gub!'. This site was made with the intention to accommodate the aspirations, concerns, or complaints against public services and also dissatisfaction with the performance of local government and the provincial government of Central Java. An increasing number of documents in text format significantly recently made the process of grouping documents (document classification) becomes important. By using the method of text classification, then the document is an overwhelming number of these are organized in such a way so as to facilitate and accelerate the search needed information. Experiments in this study aimed to classify the Indonesian language text documents using Neural Network algorithm. The test is done by using a sample of text documents taken from a web-based electronic mass media entitled 'Lapor Gub!'. The experimental results show that the neural network method effectively used to classify texts public complaints. It is seen from the experimental results, namely the use of Neural Network algorithm on the classification process produces high accuracy in the amount of $43.00 \%$ with a period of 03 hours 45 minutes 14 seconds of the Indonesian language text documents classify text public complaints.
\end{abstract}

Keywords : Classification, Neural Network, Public Complaints.

$\begin{array}{ll}\text { Dikirim } & : \text { 2019-04-01 } \\ \text { Diterima } & : 2019-04-14 \\ \text { Diterbitkan } & : 2019-04-14 \\ \text { DOI } & : \text { https://doi.org/10.29165/komtekinfo.v5i2 }\end{array}$




\section{Pendahuluan}

Penyebaran informasi dalam bentuk dokumen digital kini telah berkembang sangat pesat dan terus mengalami peningkatan, serta jumlahnya semakin besar. Media massa versi elektronik dan situs web di internet merupakan dua contoh media yang menggunakan dan menyebarkan informasi yang berbentuk dokumen digital [1]. Perkembangan yang pesat dalam informasi digital telah menyebabkan semakin meningkat pula volume informasi yang berbentuk teks. Diantara berbagai bentuk informasi digital, diperkirakan $80 \%$ dokumen digital adalah dalam bentuk teks [2].

Perkembangan internet menyebabkan meningkatnya jumlah informasi digital. Berbagai informasi bisa didapatkan dengan mudah yaitu hanya dengan meng-klik atau menekan 'enter'. Banyak informasi digital yang tersebar di dunia maya yang tidak semuanya kita perlukan. Oleh karena itu, perlu adanya pengelompokan informasi berdasarkan kontennya. Selain itu, dimensi data yang besar juga menyebabkan proses komputasi yang besar. Oleh karena itu, teknik reduksi dimensi digunakan agar dapat mengurangi waktu komputasi dan dapat mereduksi fitur-fitur yang non-informatif [3].

Web merupakan salah satu wadah tayang baik bagi orang-orang untuk mengekspresikan pendapat mereka pada berbagai topik. Bahkan pemberi opini secara profesional, seperti reviewer film, memiliki blog dimana publik dapat mengomentari dan merespon apa yang mereka pikirkan. Kemampuan untuk mengekstrak pendapat tersebut dari baris-baris teks menjadi sangat berguna dan banyak dikaji karena faktor nilai komersialnya. Dikarenakan sebagian besar informasi saat ini disimpan sebagai teks, text mining diyakini memiliki potensi nilai komersial tinggi. Text mining, mengacu pada proses mengambil informasi berkualitas tinggi dari teks. Informasi berkualitas tinggi biasanya diperoleh melalui peramalan pola dan kecenderungan melalui sarana seperti pembelajaran pola statistik. Proses text mining yang khas meliputi kategorisasi teks, text clustering, ekstraksi konsep/entitas, produksi taksonomi granular, sentiment analysis, penyimpulan dokumen, dan pemodelan relasi entitas [4].

Salah satu web yang diperuntukkan bagi masyarakat umum di provinsi Jawa Tengah yaitu web yang bernama 'Lapor Gub !'. Web ini dibuat dengan tujuan untuk menampung keluhan atau pengaduan masyarakat terhadap sektor pelayanan publik dan kinerja pemerintah daerah maupun pemerintah provinsi Jawa Tengah. Jenis pengaduan masyarakat dalam web ini meliputi berbagai sektor seperti pendidikan, infrastruktur, kepegawaian, kesehatan, dan lain-lain. Dalam web ini, seluruh masyarakat Jawa Tengah diberikan hak penuh untuk menyampaikan keluhan atau pengaduannya dalam berbagai bidang yang terjadi dalam kehidupan sehari-hari. Ada sekitar ribuan pengaduan yang telah masuk dalam web ini dari berbagai sektor. Hal ini tentu saja menyulitkan bagi dinas terkait untuk menemukan dan membaca pengaduan masyarakat sesuai dengan bidang pengaduannya. Contohnya, pengaduan di bidang pendidikan pastinya dinas pendidikanlah yang harus mengecek dan menampung pengaduan tersebut, dan begitu juga untuk dinas-dinas yang lainnya. Oleh karena itu, diperlukan metode yang efektif dan efisien untuk mengelompokkan pengaduan-pengaduan tersebut sesuai dengan bidang pengaduan yang diajukan. Pengajuan ini dituliskan dalam bentuk teks dengan menyebutkan identitas lengkap pihak yang menuliskan pengaduan, serta dilengkapi foto lokasi khusus untuk jenis pengaduan bidang infrastruktur (bangunan, jalan, dan lain-lain). Pada masing-masing kolom pengaduan masyarakat, disamping kanannya terdapat kolom komentar dari dinas terkait sesuai dengan bidang pengaduan.

Bidang yang mempelajari teknik-teknik untuk pengorganisasian dokumen teks secara umum dibagi menjadi dua kelompok, yaitu classification dan clustering. Classification adalah 
proses untuk menemukan model yang membedakan konsep atau kelas data, dengan tujuan untuk dapat memperkirakan kelas dari suatu objek yang labelnya tidak diketahui. Sedangkan clustering digunakan untuk melakukan pengelompokan data tanpa berdasarkan kelas data tertentu dan dapat digunakan untuk memberikan label pada kelas data yang belum diketahui [1].

Secara umum, klasifikasi teks telah dianggap sebagai metode penting untuk mengelola dan memproses sekian banyak dokumen digital yang senantiasa mengalami banyak perkembangan dari waktu ke waktu. Dalam proses klasifikasi teks, satu set dokumen diklasifikasikan ke dalam kategori standart dengan menggunakan teknik tertentu [18].

Mengelola informasi dari sekumpulan dokumen teks yang jumlahnya sangat besar tentunya bukan pekerjaan yang mudah. Oleh karena itu, diperlukan sebuah metode yang dapat mengorganisir dan mengklasifikasi dokumen secara otomatis, sehingga dapat mempermudah dalam pencarian informasi yang relevan/sesuai dengan kebutuhan [1]. Terdapat beberapa metode yang ada untuk pengklasifikasian dokumen yang muncul dan digunakan dalam aplikasi yang berbeda-beda. Beberapa metode pengklasifikasian dokumen yang cukup sering digunakan adalah Pohon, Nä̈ve Bayes Classifier, K-Nearest Neighbor, dan Neural Network [6].

Penelitian sebelumnya dilakukan oleh Joko Samodra [1], yaitu penelitian yang berbasis pada klasifikasi dokumen teks berbahasa Indonesia dengan menggunakan algoritma Nä̈ve Bayes. Dari penelitian tersebut diperoleh akurasi yang terbaik yaitu 87,63\%. Berdasarkan penelitian tersebut, peneliti mencoba meningkatkan akurasi dengan menggunakan metode yang berbeda untuk memperoleh tingkat akurasi yang lebih baik, dalam mengklasifikasikan dokumen teks berbahasa Indonesia yaitu dengan menggunakan algoritma Neural Network.

Beberapa peneliti pernah melakukan penelitian serupa mengenai klasifikasi dokumen teks, yaitu Amir Hamzah [2] melakukan penelitian tentang klasifikasi teks dengan Nä̈ve Bayes Classifier (NBC) untuk pengelompokan teks berita. Dari hasil penelitian ini diperoleh akurasi yang lebih tinggi (maksimal 91\%) pada teks berita dibandingkan dengan dokumen akademik (maksimal 82\%).

Penelitian berikutnya dilakukan oleh Eva Yulia Puspaningrum [3] yaitu reduksi fitur untuk kategorisasi teks dengan klasifikasi menggunakan Neural Network. Dalam penelitian ini diusulkan dengan membandingkan hasil kategorisasi teks dengan cara mereduksi fitur dengan TF/DF (Term Frequency-Inverse Document Frequency) Thresholding dan TF/DF Thresholding ditambah dengan PCA (Principal Component Analysis). Hasil yang didapatkan menunjukkan dengan reduksi fitur menggunakan TF/DF thresholding mampu mereduksi kata hingga 45,37 \% dan TF/DF Thresholding ditambah dengan PCA mampu mereduksi dokumen asli menjadi 98,5\%. Pada saat klasifikasi akurasi yang didapat setelah reduksi dimensi dengan TF/DF Thresholding mempunyai nilai akurasi yang lebih baik dibandingkan dengan hasil akurasi setelah reduksi dimensi dengan PCA.

Ni Wayan Sumartini [4] melakukan penelitian tentang text mining dengan metode Nä̈ve Bayes Classifier (NBC) dan Support Vector Machines (SVM) untuk sentiment analysis. Hasil percobaan menunjukkan bahwa metode SVM memberikan unjuk kerja yang lebih baik daripada metode NBC untuk mengklasifikasikan opini berbahasa Inggris dan opini positif berbahasa Indonesia. Sedangkan NBC memberikan unjuk kerja yang lebih baik dalam mengklasifikasikan data uji opini negatif berbahasa Indonesia. Metode NBC memberikan hasil dengan akurasi hingga $80,18 \%$ untuk data uji opini positif berbahasa Inggris, dan memberikan hasil dengan akurasi hingga $83,86 \%$ untuk data uji opini negatif berbahasa Inggris. Untuk data berbahasa Indonesia metode NBC memberikan hasil dengan akurasi hingga 74,29\% pada data uji opini positif dan hingga $87,14 \%$ pada data uji opini negatif. Metode SVM memberikan hasil dengan akurasi KomtekInfo Universitas Putra Indonesia YPTK Padang // 2019 
hingga $80,15 \%$ untuk data uji opini positif berbahasa Inggris, dan memberikan hasil dengan akurasi hingga 98,95\% untuk data uji opini negatif berbahasa Inggris. Untuk data berbahasa Indonesia metode SVM memberikan hasil dengan akurasi hingga 78,20\%, pada data uji opini positif dan hingga $78,14 \%$ pada data uji opini negatif.

Dilihat dari acuan di atas, maka peneliti menggunakan algoritma neural network dengan pertimbangan kelebihan sebagai berikut [7] :

1) Kemampuan mengakuisisi pengetahuan walaupun dalam keadaan ketidakpastian.

2) Neural network mampu menciptakan sendiri representasi melalui kemampuan belajar.

3) Kemampuan untuk memberikan toleransi atas suatu distorsi dimana gangguan kecil pada data dianggap sebagai gangguan (noise).

\section{Tinjauan Literatur}

Text mining adalah proses pengambilan data berupa teks dari sebuah sumber dalam hal ini sumbernya adalah dokumen. Dengan text mining dapat dicari kata-kata kunci yang dapat mewakili isi dari suatu dokumen lalu di analisa dan dilakukan pencocokan antara dokumen dengan database kata kunci yang telah dibuat untuk menentukan atau memilih kategori suatu dokumen. Sehingga dapat disimpulkan text mining merupakan proses menambang data yang berupa teks dimana sumber data didapatkan dari dokumen dengan tujuan mencari kata-kata yang dapat mewakili isi dari dokumen sehingga dapat dilakukan analisa keterhubungan antar dokumen [7].

Menurut Hearst [8], perbedaan mendasar antara text mining dan data mining terletak pada sumber data yang digunakan. Pada data mining, pola-pola diekstrak dari basis data yang terstruktur. Sedangkan pada text mining, pola-pola diekstrak dari data aktual. Secara umum, basis data didesain untuk program dengan tujuan untuk melakukan pemrosesan secara otomatis, sedangkan data ditulis untuk dibaca langsung oleh manusia.

Text mining merupakan suatu proses yang melibatkan beberapa area teknologi. Namun secara umum, proses-proses pada text mining mengadopsi proses data mining. Bahkan beberapa teknik dalam proses text mining juga menggunakan teknik-teknik data mining. Text mining dapat memberikan solusi dari permasalahan seperti pemrosesan, pengorganisasian / pengelompokkan dan menganalisa unstructured text dalam jumlah besar. Adapun tugas khusus dari text mining antara lain yaitu pengkategorisasian teks (text categorization) dan pengelompokan teks (text clustering). Ada empat tahap proses pokok dalam text mining, diataranya pemrosesan awal terhadap data (data preprocessing), transformasi data (data transformation), pemilihan fitur (feature selection), dan penemuan pola (pattern discovery) [9].

\section{Data Preprocessing}

Tahap ini melakukan analisis semantic (kebenaran arti) dan sintaktik (kebenaran susunan) terhadap data. Tujuan dari pemrosesan awal adalah untuk mempersiapkan data menjadi data yang akan mengalami pengolahan lebih lanjut. Operasi yang dapat dilakukan pada tahap ini, meliputi Part-of-Speech (PoS) tagging, menghasilkan parse tree untuk tiaptiap kalimat, dan pembersihan data. 


\section{Data Transformation}

Transformasi data atau pembentukan atribut mengacu pada proses untuk mendapatkan representasi dokumen yang diharapkan. Transformasi data sekaligus juga melakukan pengubahan kata-kata ke bentuk dasarnya serta pengurangan dimensi kata di dalam dokumen. Tindakan ini diwujudkan dengan menerapkan stemming dan menghapus stopwords.

\section{Feature Selection}

Pemilihan fitur merupakan tahap lanjut dari penguranga dimensi pada proses transformasi data. Walaupun pada tahap sebelumnya sudah melakukan penghapusan kata-kata yang tidak deskriptif (stopwords), namun tidak semua kata-kata di dalam dokumen memiliki arti penting. Oleh karena itu, untuk mengurangi dimensi, maka pemilihan hanya dilakukan terhadap kata-kata yag berhubungan dan benar-benar merepresentasikan isi dari suatu dokumen. Ide dasar dari pemilihan fitur adalah menghapus kata-kata yang kemunculannya dalam suatu dokumen terlalu sedikit atau terlalu banyak.

Algoritma yang digunakan pada text mining biasanya tidak hanya melakukan perhitungan pada dokumen saja, tetapi juga pada feature. Ada empat jenis feature yang umum digunakan, diantaranya :

a) Character, merupakan komponen individual, bisa berupa huruf, angka, karakter spesial, dan spasi. Character merupakan block pembangun pada level paling tinggi pembentuk semantic feature, seperti kata dan term. Pada umumnya, representasi character-based jarang digunakan pada beberapa teknik pemrosesan data.

b) Words, merupakan kumpulan karakter yang memiliki pola yang sama pada character.

c) Terms, merupakan single word dan multiword phrase yang terpilih secara langsung dari corpus. Representasi term-based dari dokumen tersusun dari subset term dalam dokumen.

d) Concept, merupakan feature yang di generate dari sebuah dokumen secara manual, rule based, atau metodologi lain [14].

\section{Patter Discovery}


Pattern discovery merupakan tahap penting untuk menemukan pola atau pengetahuan dari keseluruhan data. Tindakan yang lazim dilakukan pada tahap ini berupa operasi text mining.

Secara umum, klasifikasi teks telah dianggap sebagai metode penting untuk mengelola dan memproses sekian banyak dokumen digital yang senantiasa mengalami banyak perkembangan dari waktu ke waktu. Dalam proses klasifikasi teks, satu set dokumen diklasifikasikan ke dalam kategori standart dengan menggunakan teknik tertentu [18].

Teks yang akan dilakukan proses text mining [19], pada umumnya memiliki beberapa karakteristik diantaranya adalah memiliki dimensi yang tinggi, terdapat noise pada data, dan terdapat struktur teks yang tidak baik. Cara yang digunakan dalam mempelajari suatu data teks, adalah dengan terlebih dahulu menentukan fitur-fitur yang mewakili setiap kata untuk setiap fitur yang ada pada dokumen. Sebelum menentukan fitur-fitur yang mewakili, diperlukan tahap preprocessing. Preprocessing merupakan proses awal yang diterapkan terhadap data teks yang bertujuan untuk menghasilkan data numerik. Data preprocessing menerangkan tipe-tipe proses yang melaksanakan data mentah untuk mempersiapkan proses prosedur yang lainnya. Tujuan preprocessing adalah mentransformasi data ke suatu format yang prosesnya lebih mudah dan efektif untuk kebutuhan pemakai, dengan indikator sebagai berikut [20] :

1. Mendapatkan hasil yang lebih akurat.

2. Pengurangan waktu komputasi untuk large scale problem.

3. Membuat nilai data menjadi lebih kecil tanpa merubah informasi yang dikandungnya.

Tahap preprocessing yang dilakukan secara umum dalam text mining pada dokumen, yaitu case folding, tokenizing, filtering (Delete Stopwords), stemming, tagging, dan analyzing. Setelah proses ini, sebuah set fitur awal diproduksi dan masalah dapat mewakili sebagai vektor fitur dengan menggunakan metode jangka bobot tertentu untuk mengukur [18].

Proses pengurangan fitur merupakan pengurangan dimensi dari ruang fitur untuk meningkatkan skalabilitas dari text classifier. Ada dua jenis metode pengurangan fitur, yaitu seleksi fitur dan fitur transformasi. Setelah pengurangan fitur, vektor fitur dapat berkurang dan mudah direpresentasikan dalam bentuk yang dapat menjadi masukan bagi algoritma klasifikasi teks dan akhirnya masih bisa mengklasifikasikan [19]. Gambar 1 di bawah ini menunjukkan tahap-tahap preprocessing yang dilakukan secara umum dalam text mining pada dokumen, yaitu [18] :

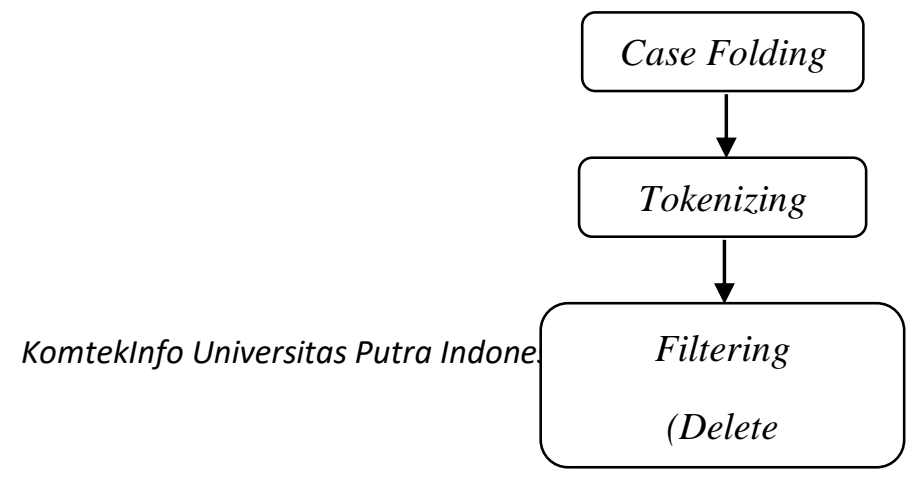




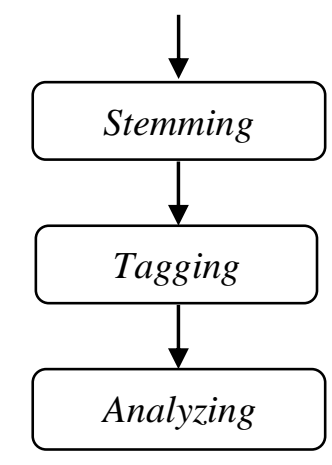

Gambar 1 : Tahap Preprocessing

a) Case Folding

Case folding adalah mengubah semua huruf dalam dokumen menjadi huruf kecil dan menghilangkan semua tanda baca. Hanya huruf 'a' sampai dengan ' $z$ ' yang diterima. Karakter selain huruf dihilangkan dan dianggap delimiter.

b) Tokenizing

Ialah tahap pemotongan string input atau dokumen berdasarkan tiap kata yang menyusunnya.

c) Filtering (Delete Stopwords)

Tahap filtering adalah tahap mengambil kata-kata penting dari hasil token. Bisa menggunakan algoritma stop list (membuang kata yang kurang penting) atau word list (menyimpan kata penting). Filtering (Delete Stopwords) merupakan langkah dari preprocessing dengan menghilangkan kata yang kurang sesuai, seperti kata kerja bantu, konjungsi (penghubung) dan artikel yang tidak penting dalam pelatihan classifier.

\section{d) Stemming}

Tahap stemming adalah tahap mencari root kata dari tiap kata hasil filtering. Tahap ini kebanyakan dipakai untuk teks berbahasa Inggris. Hal ini dikarenakan bahasa Indonesia tidak memiliki rumus bentuk baku yang permanen. Stemming yaitu langkah preprocessing umum dengan mengurangi ukuran fitur awal yang ditetapkan. Proses stemming dapat dilakukan dengan menjadikan setiap kata ke dalam bentuk kata dasar.

e) Tagging

Tahap tagging ialah tahap mencari bentuk awal/root dari tiap kata lampau atau kata hasil stemming. Tahap ini hanya dipakai untuk teks berbahasa Inggris. Hal ini dikarenakan bahasa Indonesia tidak memiliki bentuk lampau. 


\section{f) Analyzing (Vector Representasi For Text)}

Tahap analyzing merupakan tahap penentuan seberapa jauh keterhubungan antara katakata dalam dokumen yang ada. Setelah proses tokenization teks dan menghapus kata-kata yang tidak sesuai, tahap selanjutnya adalah pembobotan fitur. Pilihan fitur atau kunci tambahan rekayasa merupakan representasi dari nilai fitur. Seringkali 'boolean' indikator kata terjadi pada dokumen. Kemungkinan lain termasuk perhitungan berapa kali kata terjadi dalam dokumen, frekuensi terjadinya dinormalisasi oleh panjang dokumen, dan jumlah dinormalisasi oleh kebalikan dokumen frekuensi kata. Dalam situasi dimana panjang dokumen bervariasi, mungkin penting untuk menormalkan jumlah. Selanjutnya dalam jangka pendek, dokumen kata tidak mungkin untuk mengulang, membuat 'boolean' kata indikator hampir sebagai informasi penting. Ini menghasilkan penghematan besar dalampelatihan sumber daya dan dalam ruang pencarian dari induksi algoritma. Selanjutnya yaitu mencari jumlah kata terbuang dan ambang batas pada masing-masing karakter. Sebagian besar algoritma teks kategorisasi dalam sastra merupakan dokumen sebagai koleksi kata. Sebuah alternatif yang belum cukup dieksplorasi ialah penggunaan arti kata yang juga dikenal sebagai indera.

Pembobotan kata / term weighting adalah proses untuk memberikan nilai pada sebuah kata. Kata yang memiliki nilai signifikan pada proses machine learning akan memiliki nilai bobot yang tinggi, sebaliknya kata yang tidak memberikan pengaruh signifikan pada proses machine learning akan memiliki nilai bobot yang rendah.

Untuk proses pembobotan kata akan digunakan perhitungan Term Frequency-Inverse Document Frequency (TF-IDF). Sebuah kata akan memilih nilai TF-IDF tinggi jika memiliki frekuensi kemunculan yang tinggi namun jumlah dokumen yang memuat kata tersebut dalam corpus sedikit. TF-IDF merupakan produk hasil perkalian dari 2 nilai statistik yaitu term frequency (TF), dan Inverse Document Frequency (IDF). Secara matematis, menunjukkan formula matematis dari TF-IDF, dimana $\mathrm{t}$ menyatakan kata yang dicari nilainya, $\mathrm{d}$ menyatakan dokumen yang mengandung kata tersebut, dan D menyatakan koleksi dari dokumen secara keseluruhan [19].

Florin Gorunescu [10] menyebutkan bahwa Confusion Matrix digunakan untuk evaluasi kinerja model klasifikasi yang berdasarkan pada kemampuan akurasi prediktif suatu model. Akurasi prediktif merupakan parameter untuk mengukur ketepatan aturan klasifikasi yang dihasilkan dalam mengklasifikasikan test set berdasarkan atribut yang ada ke dalam kelasnya.

Akurasi ialah fungsi umum yang digunakan untuk mengukur efektivitas pada teknik klasifikasi. Namun nilai akurasi yang jauh lebih sedikit kurang tepat untuk mengukur variasi jumlah keputusan yang tepat dari Presisi dan Recall [19]. Akurasi dinyatakan dalam persentase (\%), sehingga aturan dengan akurasi $100 \%$ artinya semua kasus yang terangkum oleh aturan klasifikasi telah diklasifikasikan dengan benar ke dalam kelas yang diprediksinya.

Untuk mendapatkan nilaiakurasi prediktif diperlukan perhitungan jumlah data yang diprediksikan dengan benar dan jumlah data yang diprediksikan dengan salah. Perhitungan tersebut lalu ditabulasikan ke dalam tabel yang disebut Confusion Matrix [10].

Tabel 1 : Confusion Matrix

KomtekInfo Universitas Putra Indonesia YPTK Padang // 2019 


\begin{tabular}{|l|c|c|c|}
\hline \multirow{4}{*}{ Actual Class } & \multicolumn{3}{|c|}{ Predicted Class } \\
\cline { 2 - 4 } & & Tepat Waktu & Tidak Tepat Waktu \\
\cline { 2 - 4 } & Tepat Waktu & True Positive (TP) & False Negative (FN) \\
\cline { 2 - 4 } & Tidak Tepat Waktu & False Positive (FP) & True Negative (TN) \\
\hline
\end{tabular}

True Positive (TP) : Masalah yang diklasifikasikan berkaitan dengan kategori yang benar.

False Positive (FP) : Masalah yang diklasifikasikan berkaitan dengan kategori yang salah.

True Negative (TN) : Masalah yang diklasifikasikan tidak berkaitan dengan kategori yang benar.

False Negative (FN) : Masalah yang diklasifikasikan tidak berkaitan dengan kategori yang salah [19].

Menghitung akurasi dapat dilakukan dengan rumus [10] :

$$
\text { Accuracy }=\frac{\mathrm{TP}+\mathrm{TN}}{(\mathrm{TP}+\mathrm{TN}+\mathrm{FP}+\mathrm{FN})} \times 100 \%
$$

atau :

$$
\text { Accuracy }=\frac{\text { Jumlah kasus yang diprediksikan dengan benar }}{\text { Total jumlah kasus }}
$$

Sedangkan untuk menghitung Recall ialah :

$$
\text { Recall }=\frac{\mathrm{TP}}{(\mathrm{TP}+\mathrm{FP})}
$$

atau : 


$$
\text { Recall }=\frac{\mathrm{TN}}{(\mathrm{TN}+\mathrm{FN})}
$$

Untuk menghitung Precision yaitu :

$$
\text { Precision }=\frac{\mathrm{TP}}{(\mathrm{TP}+\mathrm{FN})}
$$

atau :

$$
\text { Precision }=\frac{\mathrm{TN}}{(\mathrm{TN}+\mathrm{FP})}
$$

Sedangkan untuk mengukur tingkat error menggunakan rumus berikut :

$$
\text { Error }=1-\text { accuracy }
$$

Siang [16] menjelaskan bahwa sejarah jaringan saraf tiruan pertama kali secara sederhana diperkenalkan oleh McCulloch dan Pitts pada tahun 1943. McCulloch dan Pitts menyimpulkan bahwa kombinasi beberapa neuron sederhana menjadi sebuah sistem neural akan meningkatkan kemampuan komputasinya. Bobot dalam jaringan yang diusulkan oleh McCulloch dan Pitts diatur untuk melakukan fungsi logika sederhana. Fungsi aktivasi yang dipakai adalah fungsi thresholding.

Jaringan Saraf Tiruan (JST) atau disebut juga dengan Neural Network (NN)), adalah jaringan dari sekelompok unit pemroses kecil yang dimodelkan berdasarkan jaringan saraf manusia. Jaringan saraf tiruan merupakan sistem adaptif yang dapat merubah strukturnya untuk memecahkan masalah berdasarkan informasi eksternal maupun internal yang mengalir melalui jaringan tersebut. Secara sederhana, JST adalah sebuah alat pemodelan data statistik non-linier. JST dapat digunakan untuk memodelkan hubungan yang kompleks antara input dan output untuk menemukan pola-pola pada data [23].

Neural network merupakan metode yang berusaha untuk meniru fungsi otak manusia. Otak manusia diyakini terdiri dari jutaan unit pengolahan kecil yang disebut neuron dan bekerja secara paralel. Generalized Regression Neural Network (GBNN) adalah kemampuan ANN untuk memberikan jawaban yang benar pada input yang tidak diketahui. Generalisasi merupakan ukuran dari seberapa baik sistem telah dilatih. Generalisasi diukur dengan kinerja dari sistem untuk mengatur data pengujian [22]. 
JST ditentukan oleh 3 hal [25]:

a) Pola hubungan antar neuron (disebut arsitektur jaringan).

b) Metode untuk menentukan bobot penghubung (disebut metode training/learning/algoritma).

c) Fungsi aktivasi (fungsi transfer).

Neuron dalam jaringan saraf tiruan sering diganti dengan istilah simpul. Setiap simpul tersebut berfungsi untuk menerima atau mengirim sinyal dari atau ke simpul-simpul lainnya. Pengiriman sinyal disampaikan melalui penghubung. Kekuatan hubungan yang terjadi antara setiap simpul yang saling terhubung dikenal dengan nama bobot.

Artificial Neural Network (ANN) diperkenalkan untuk menstimulasi mekanisme kerja biologis jaringan saraf,yang terdiri atas bermacam-macam unit yang disebut neuron dan terhubung satu sama lain [11]. ANN berusaha untuk meniru struktur dan cara kerja otak manusia sehingga mampu menggantikan beberapa pekerjaan manusia, seperti mengenali pola (pattern recognition), prediksi, klasifikasi, dan pendekatan fungsi optimasi.

Artificial neuron terdiri dari sejumlah input. Informasi ini diberikan sebagai masukan melalui input koneksi, masing-masing yang memiliki beberapa berat yang berhubungan dengan itu. Masukan tambahan yang dikenal diberikan ke artificial neuron. Neuron juga terdiri dari satu output. Outputnya ialah terbentuk dari pengolahan berbagai input oleh neuron [23].

Arsitektur jaringan saraf tiruan digolongkan menjadi 3 model, yaitu [3] :

1) Jaringan Layar Tunggal

Dalam jaringan ini, sekumpulan input neuron dihubungkan langsung dengan sekumpulan outputnya.

2) Jaringan Layar Jamak

Jaringan ini merupakan perluasan dari layar tunggal. Dalam jaringan ini, selain unit input dan output, ada unit-unit lain yang sering disebut layar tersembunyi. Layar tersembunyi ini bisa saja lebih dari satu [16].

3) Jaringan Reccurent

KomtekInfo Universitas Putra Indonesia YPTK Padang // 2019 
Model jaringan recurrent mirip dengan jaringan layar tunggal ataupun ganda. Hanya saja, ada neuron output yang memberikan sinyal pada unit input (sering disebut feedback loop). Dengan kata lain sinyal mengalir dua arah, yaitu maju dan mundur [16].

Backpropagation adalah salah satu metode dari jaringan saraf tiruan yang dapat diaplikasikan dengan baik dalam bidang peramalan (forecasting). Backpropagation melatih jaringan untuk mendapatkan keseimbangan antara kemampuan jaringan mengenali pola yang digunakan selama training serta kemampuan jaringan untuk memberikan respon yang benar terhadap pola masukan yang serupa namun tidak sama dengan pola yang dipakai selama pelatihan [22].

Penemuan algoritma Backpropagation untuk multilayer perceptron merupakan metode yang sistematis untuk training sehingga bisa dilakukan dan lebih efisien. Algoritma Backpropagation berasal dari learning rule Widrow dan Hoff, disusun oleh Werbos (1974), dibuat oleh Parker (1985), Rumelhart Hinton, William, dan peneliti lainnya [26].

Backpropagation merupakan algoritma pembelajaran yang terwarisi dan biasanya digunakan oleh perceptron dengan banyak lapisan untuk mengubah bobot-bobot yang terhubung dengan neuron-neuron yang ada pada lapisan hidden (tersembunyi). Algoritma backpropagation menggunakan error output untuk mengubah nilai-nilai bobotnya dalam arah mundur (backward). Tahap perambatan maju (forward propagation) harus dikerjakan terlebih dahulu untuk mendapatkan nilai error tersebut [10].

Multilayer Perceptron (MLP) disebut juga multilayer feedforward neural network merupakan algoritma yang paling luas digunakan. Menurut Wong, Bodnovich, dan Selvi [16], sekitar 95\% aplikasi bisnis menggunakan neural network. Salah satu kelebihan neural network adalah cukup baik dalam menangani data yang mengandung noise [15].

MLP terdiri dari input layer, satu atau lebih hidden layer, dan output layer. Berikut penjelasan masing-masing layer [16] :

\section{1) Input Layer}

Input layer untuk menerima nilai masukan dari tiap record pada data. Jumlah simpul input sama dengan jumlah variabel prediktor.

\section{2) Hidden Layer}

Hidden layer mentransformasikan nilai input di dalam network. Tiap simpul pada hidden layer terhubung dengan simpul-simpul pada hidden layer sebelumnya atau dari simpulsimpul pada input layer dan ke simpul-simpul pada hidden layer berikutnya atau ke simpulsimpul pada output layer. 


\section{3) Output Layer}

Garis yang terhubung dengan output layer berasal dari hidden layer atau input layer dan mengembalikan nilai keluaran yang bersesuaian dengan variabel prediksi. Keluaran dari output layer biasanya merupakan nilai floating antara 0 sampai 1 [27].

Ada 3 fase Pelatihan backpropagation, antara lain [10]:

a) Fase 1, yaitu Propagasi Maju.

Dalam propagasi maju, setiap sinyal masukan dipropagasi (dihitung maju) ke layar tersembunyi hingga layar keluaran dengan menggunakan fungsi aktivasi yang ditentukan.

b) Fase 2, yaitu Propagasi Mundur.

Kesalahan (selisih antara keluaran jaringan dengan target yang diinginkan) yang terjadi dipropagasi mundur mulai dari garis yang berhubungan langsung dengan unit-unit di layar keluaran.

c) Fase 3, yaitu Perubahan Bobot.

Pada fase ini dilakukan modifikasi bobot untuk menurunkan kesalahan yang terjadi. Ketiga fase tersebut diulang-ulang terus hingga kondisi penghentian dipenuhi.

Haryono [29], Chi-Square atau Chi-Kuadrat lainnya ialah sebuah uji hipotesis tentang perbandingan antara frekuensi observasi dengan frekuensi harapan yang didasarkan oleh hipotesis tertentu pada setiap kasus atau data. Chi-Kuadrat adalah pengujian hipotesis tentang perbandingan antara frekuensi sampel yang benar-benar terjadi. Chi-Kuadrat biasanya di dalam frekuensi observasi berlambangkan dengan frekuensi harapan yang didasarkan atas hipotesis dilambangkan. Ekspresi matematis tentang distribusi Chi-Kuadrat hanya tergantung pada suatu parameter, yaitu derajat kebebasan (d.f.) [30].

Chi-Kuadrat mempunyai masing-masing nilai derajat kebebasan, yaitu distribusi (kuadrat standard normal) merupakan distribusi Chi-Kuadrat dengan d.f. $=1$, dan nilai variabel tidak bernilai negatif. Kegunaan dari Chi-Square untuk menguji seberapa baik kesesuaian diantara frekuensi yang teramati dengan frekuensi harapan yang didasarkan pada sebaran yang akan dihipotesiskan, atau juga menguji perbedaan antara dua kelompok pada data dua kategorik untuk dapat menguji signifikansi asosiasi dua kelompok pada data dua katagorik tersebut [31].

Adapun kegunaan dari uji Chi-Square, adalah [29] :

1) Ada tidaknya asosiasi antara 2 variabel (Independent test).

2) Apakah suatu kelompok homogen atau tidak (Homogenity test).

3) Uji kenormalan data dengan melihat distribusi data (Goodness of fit test).

KomtekInfo Universitas Putra Indonesia YPTK Padang // 2019 
Uji Chi-square biasa digunakan pada uji statistik non-parametrik. Chi-square merupakan metode statistik yang dibuat oleh Karl Pearson pada tahun 1900, sehingga metode sering juga disebut Pearson's Chi-square. Levine [31], Chi-square dapat digunakan untuk test of independence atau menguji kebebasan antara dua kategori variabel. Untuk Chi-square, hipotesis yang digunakan adalah mengenai ada atau tidaknya hubungan atau kaitan antara dua kategori variabel secara statistik, seperti:

$H_{0}$ : Kedua kategori variabel adalah independen atau saling bebas (tidak terdapat hubungan antara kedua kategori variabel).

$H_{1}$ : Kedua kategori variabel adalah dependen atau saling terikat (terdapat hubungan antara kedua kategori variabel).

Rumus yang digunakan untuk uji statistik dengan Chi-Square adalah [31] :

$$
X^{2}=\sum_{\text {allcells }} \frac{\left(f_{0}-f_{e}\right)^{2}}{f_{e}}
$$

\section{Keterangan :}

$f_{0}=$ frekuensi yang diobservasi dari cell tertentu dari contingency table.

$f_{e}=$ frekuensi yang diharapkan dari cell tertentu.

Contingency table merupakan cara pemetaan data dengan memaparkan frekuensi dari masing-masing kategori variabel seperti matriks frekuensi. Persyaratan uji statistik Chi-Square adalah menolak $H_{0}$ pada level of significance $(\alpha)$ tertentu jika nilai perhitungan statistik $\left(X^{2}\right)$ lebih besar dari nilai pada Tabel Chi-Square $\left(X_{u}^{2}\right)$ dengan nilai kebebasan (degrees of freedom) sama dengan $(r-1)(c-1)$ dimana $r$ adalah jumlah baris dan $c$ adalah jumlah kolom pada contingency table [32]. 
Seleksi fitur adalah salah satu tahapan pra-proses yang berguna terutama dalam mengurangi dimensi data, menghilangkan data yang tidak relevan, serta meningkatkan hasil akurasi [34]. Jain dan Zongker [33], mendefinisikan masalah seleksi fitur sebagai berikut : diberikan sekumpulan fitur lalu dipilih beberapa fitur yang mampu memberikan hasil yang terbaik pada klasifikasi. Ada dua titik berat seleksi fitur dengan pendekatan machine learning menurut Portiale yaitu memilih fitur yang akan digunakan dan menjelaskan secara konsep bagaimana mengkombinasikan fitur-fitur tersebut untuk menghasilkan konsep induksi yang benar atau hasil yang sesuai.

Seleksi fitur digunakan untuk memberikan karakterisik dari data. Seleksi fitur merupakan salah satu penelitian yang banyak dilakukan di berbagai bidang seperti pattern recognition, process identification, dan time series modelling [34].

Dalam penelitian ini digunakan algoritma Neural Network Backpropagation, yang merupakan tipe jaringan saraf tiruan dan dukungan mesin vektor digunakan untuk mengklasifikasikan teks pengaduan masyarakat pada website "Lapor Gub !".

\section{Metodologi}

Metode penelitian yang digunakan dalam penelitian ini adalah metode eksperimen. Wiersma [28] mendefinisikan bahwa eksperimen sebagai suatu penelitian yang sekurangkurangnya memiliki satu variabel bebas, yang disebut sebagai variabel eksperimental dan sengaja dimanipulasi oleh peneliti. Pada penelitian ini yang bertindak sebagai variabel bebas yaitu algoritma Neural Network Backpropagation, sedangkan klasifikasi teks pengaduan masyarakat sebagai variabel terikat.

Pada penelitian ini, dataset yang digunakan ialah data dalam bentuk teks pengaduan masyarakat yang terdapat pada web berjudul 'Lapor Gub !'. Data pengaduan masyarakat tersebut diolah dengan text mining, sehingga akan diperoleh klasifikasi teks. Pada penelitian ini akan dilakukan beberapa langkah atau tahapan penelitian seperti pada gambar 2 berikut ini [11] :

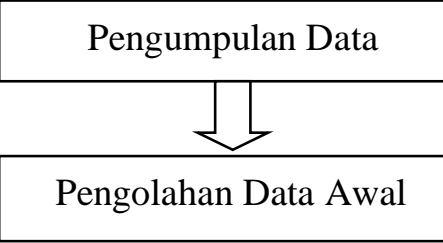

KomtekInfo Universitas Putra Indonesia YPTK Padang // 2019 


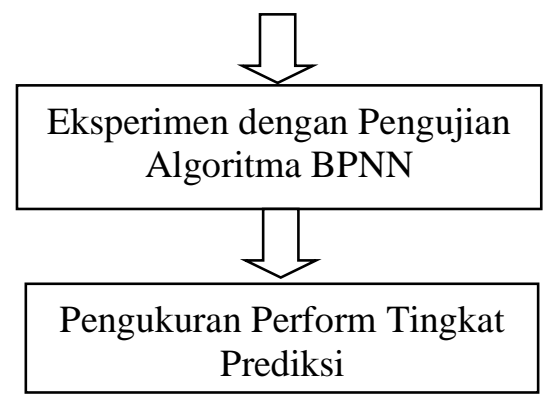

Gambar 2 : Tahapan Penelitian

Spesifikasi perangkat keras dan lunak yang digunakan untuk mendukung penelitian ini disajikan pada tabel di bawah ini :

Tabel 2 : Spesifikasi Perangkat Keras dan Lunak

\begin{tabular}{|c|l|l|}
\hline No. & \multicolumn{1}{|c|}{ Spesifikasi } & \multicolumn{1}{c|}{ Tipe } \\
\hline 1. & Processor & Intel Core 2 Duo \\
\hline 2. & Memori & $1 \mathrm{~Gb}$ \\
\hline 3. & Monitor & LCD \\
\hline 4. & Sistem Operasi & Windows 8 \\
\hline 5. & Aplikasi & Rapid Miner 5.3 \\
\hline
\end{tabular}

Teknik pengumpulan data merupakan teknik atau cara-cara yang dapat digunakan untuk mengumpulkan data [28]. Dalam pengumpulan data terdapat sumber data, yang terdiri dari dua macam yaitu sumber primer jika data yang dibutuhkan dihimpun langsung oleh peneliti, dan sumber sekunder jika data yang dibutuhkan diperoleh melalui pihak kedua.

Pada penelitian ini, data yang diperoleh merupakan jenis data primer karena diperoleh langsung oleh peneliti pada web 'Lapor Gub !'. Data yang diperoleh dalam penelitian ini ialah data kualitatif. Data yang digunakan yaitu dalam bentuk teks pengaduan masyarakat kepada Pemprov Jateng yang ada di web tersebut. Data yang akan digunakan sebagai sampel dalam penelitian ini sebanyak 300 data dari 10 sektor atau bidang pengaduan masyarakat yang diambil dari web laporgub.jatengprov.go.id. Data pengaduan yang diambil pada periode 07 Mei 2014 s/d 07 Januari 2015. Diambil jumlah dataset yang sama pada masing-masing kategori untuk memperoleh tingkat keakuratan yang sesuai dan efektif. Pada bidang kesehatan terdapat sebanyak 30 pengaduan masyarakat dalam periode waktu di atas, sehingga pada 9 bidang lainnya juga diambil sebanyak 30 dataset. Data berupa teks diambil dari web tersebut lalu disimpan dalam bentuk format txt (penyimpanan pada notepad). Berikut rincian dataset yang akan digunakan oleh peneliti, diantaranya : 
Tabel 3 : Sampel Dataset Berdasarkan Bidang Pengaduan

\begin{tabular}{|c|l|c|}
\hline No. & \multicolumn{1}{|c|}{ Bidang Pengaduan } & Jumlah \\
\hline 1. & Energi & 30 \\
\hline 2. & Infrastruktur & 30 \\
\hline 3. & Kepegawaian & 30 \\
\hline 4. & Kependudukan & 30 \\
\hline 5. & Kesehatan & 30 \\
\hline 6. & Keuangan dan Aset & 30 \\
\hline 7. & Pendidikan & 30 \\
\hline 8. & Pertanian & 30 \\
\hline 9. & Sektor Lain-Lain & 30 \\
\hline 10. & Sosial Masyarakat & 30 \\
\hline & $\quad$ Jumlah & 300 \\
\hline
\end{tabular}

Jumlah data awal yang diperoleh dari pengumpulan data yaitu sebanyak 300 data dan semua data akan digunakan. Untuk mendapatkan data yang berkualitas, ada beberapa teknik yang dapat dilakukan, antara lain [28] :

1) Data Validation

Untuk mengidentifikasi jika terdapat data yang mengganjal (ada noise, tidak lengkap), maka dilakukan penghapusan terhadap data yang mengganjal tersebut (missing value).

2) Data Integration and Transformation

Teknik ini dilakukan untuk meningkatkan akurasi dan efisiensi algoritma. Data yang digunakan dalam penelitian ini bernilai kategorikal. Data ditransformasikan ke dalam software atau tools Rapid Miner.

\section{3) Data Size Reduction and Dicrtization}

Untuk memperoleh dataset dengan jumlah atribut dan record yang lebih sedikit tetapi bersifat informatif, dapat dilakukan dengan menghapus atribut yang tidak informatif. Namun dalam penelitian ini tidak perlu ada penghapusan dikarenakan hanya satu atribut yang dipakai yaitu teks atau kalimat pengaduan masyarakat. 
Berikut ini adalah fungsi untuk mengukur efektifitas pada klasifikasi teks. Perform yang diukur meliputi akurasi (accuracy) dan tingkat error [19] :

Accuracy $=\frac{\sum \text { Prediksi semua bidang pengaduan }}{\sum \text { Semua bidang pengaduan }} \times \mathbf{1 0 0 \%}$

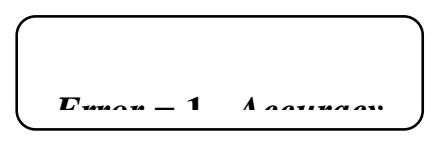

Untuk melakukan eksperimen, maka diperlukan kerangka kerja (framework) klasifikasi teks atau kalimat pengaduan masyarakat. Susunan kerangka kerja tersebut sebagai berikut :

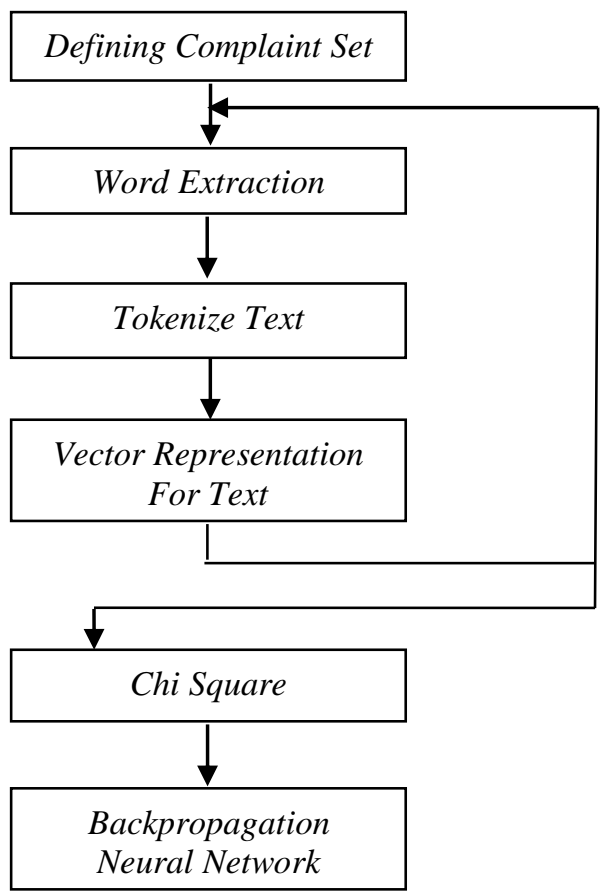

Gambar 3 : Kerangka Kerja Klasifikasi Teks Pengaduan Masyarakat

\section{Defining Complaint Set}

Terdapat sebanyak 300 dataset pengaduan masyarakat yang akan dibuktikan dengan eksperimen melalui tahap preprocessing.

\section{Word Extraction}

Menghilangkan semua tanda baca pada setiap kalimat pengaduan masyarakat.

\section{Tokenize Text}

Pemotongan string input atau dokumen berdasarkan tiap kata yang menyusunnya.

\section{Vector Representation For Text}

Setelah proses tokenization kata dan menghapus kata-kata yang tidak sesuai, tahap berikutnya adalah pembobotan fitur menggunakan TF-IDF (Term Frequency-Inverse KomtekInfo Universitas Putra Indonesia YPTK Padang // 2019 
Document Frequency). Pilihan fitur atau kunci tambahan rekayasa merupakan representasi dari nilai fitur.

\section{DF Vector Reduction}

Menghitung frekuensi kemunculan setiap kata pada setiap dataset.

\section{Backpropagation Neural Network}

Penggunaan algoritma Neural Network Backpropagation untuk mengklasifikasikan teks pengaduan masyarakat, selanjutnya pengukuran perform tingkat prediksi (akurasi).

\section{Analysis and Evaluation}

Analisa dan evaluasi dari proses-proses di atas apakah klasifikasi hasil pengujian sesuai dengan klasifikasi teks atau kalimat pengaduan yang sebenarnya.

Dalam penelitian ini digunakan model Neural Network Backpropagation. Model ini dianggap lebih baik untuk klasifikasi teks atau kalimat pengaduan masyarakat, karena $N N$ Backpropagation merupakan tipe jaringan saraf tiruan yang menggunakan metode pembelajaran terbimbing (supervised learning), sehingga algoritma ini dinilai cukup ideal digunakan untuk menghasilkan nilai akurasi yang tinggi.

Pada bagian ini akan menjelaskan tentang evaluasi hasil eksperimen dari penggunaan algoritma Neural Network Backpropagation untuk klasifikasi teks pengaduan masyarakat. Analisa dan evaluasi dalam penelitian ini ialah untuk menguji apakah klasifikasi hasil pengujian sesuai dengan klasifikasi teks atau kalimat pengaduan yang sebenarnya pada masing-masing kategori yang telah ditentukan.

\section{Hasil dan Diskusi}

Komponen yang akan dijadikan sebagai bahan pengujian diantaranya input data set teks pengaduan masyarakat yang diambil dari web laporgub.jatengprov.go.id. Data pengaduan yang diambil pada periode 07 Mei 2014 s/d 07 Januari 2015. Data berupa teks diambil dari web tersebut lalu disimpan dalam bentuk format txt (penyimpanan pada notepad). Jumlah data set yang ada yaitu sebanyak 300 data set, terdiri dari 10 kategori dengan masing-masing kategori ada 30 data set, diantaranya Infrastruktur, Sosial Masyarakat, Kependudukan, Energi, Kesehatan, Keuangan dan Aset, Pertanian, Sektor Lain-Lain, Pendidikan, dan Kepegawaian.

Eksperimen yang dilakukan untuk mengukur tingkat akurasi dari algoritma Neural Network dalam mengklasifikasikan dokumen teks pengaduan masyarakat, dengan pemakaian tokenizing dan seleksi fitur ( $\mathrm{p}=0.01,0.02,0.03,0.04,0.05,0.06,0.07,0.08,0.09,0.1,0.2$, dan 0.3).

Pencarian dengan seleksi fitur untuk akurasi tertinggi dilakukan dengan pemakaian tokenizing saja. Langkah-langkah eksperimen yang dilakukan sebagai berikut :

1) Eksperimen diawali dengan memasukkan komponen process document from file. 
2) Klik dua kali pada komponen process document from file untuk dapat meletakkan komponen tokenizing.

3) Selanjutnya untuk memasukkan algoritma Neural Network diawali dengan memilih menu editnew building block.

4) Tambahkan komponen Weight By Chi Square Statistic dan Select By Weight.

5) Terakhir, atur seleksi fitur (p) dengan nilai 0,01 sampai dengan 0,3 .

Untuk proses pembobotan kata digunakan perhitungan Term Frequency-Inverse Document Frequency (TF-IDF). Sebuah kata akan memilih nilai TF-IDF tinggi jika memiliki frekuensi kemunculan yang tinggi namun jumlah dokumen yang memuat kata tersebut dalam corpus sedikit dan sebaliknya.

Peneliti melakukan ekperimen dengan pemakaian tokenizing pada klasifikasi teks pengaduan masyarakat dengan nilai seleksi fitur (p) 0,01 sampai dengan 0,3 dan menggunakan beberapa label mulai dari 4 sampai dengan 10 label atau kategori pada masing-masing nilai $P$. Total jumlah eksperimen sebanyak 84 kali eksperimen dengan jumlah label yang berbeda-beda. Pada hasil eksperimen terlihat bahwa semakin banyak label yang digunakan dan semakin tinggi nilai P (seleksi fitur) dalam eksperimen, maka cenderung semakin lama waktu yang dibutuhkan dalam melakukan klasifikasi teks pengaduan masyarakat ini serta nilai akurasi yang dihasilkan pun cenderung semakin kecil.

Berdasarkan tabel di atas, diketahui bahwa nilai akurasi tertinggi dihasilkan dari eksperimen dengan tokenizing pada seleksi fitur (p) sama dengan 0,08 dengan nilai akurasi sebesar $43,00 \%$. 


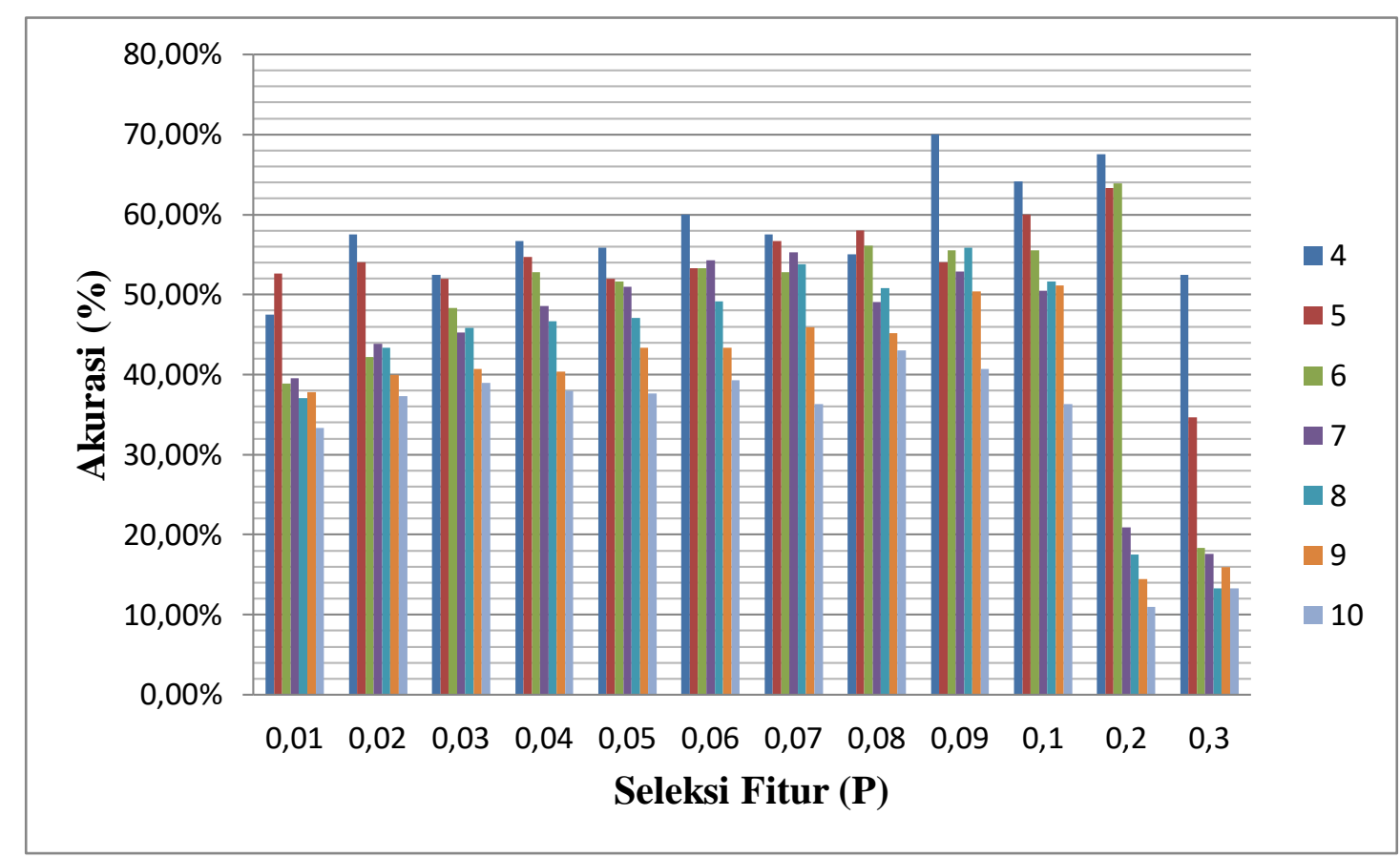

Gambar 4 : Grafik Tingkat Akurasi Teks Pengaduan Masyarakat Dengan $\mathrm{P}=0,01-0,3$

Berdasarkan data grafik pada gambar 4 di atas, dapat diketahui bahwa nilai akurasi tertinggi diperoleh dari hasil eksperimen pada seleksi fitur dengan $\mathrm{p}=0,08$ yaitu sebesar $43,00 \%$ dengan jangka waktu selama 03 jam 45 menit 14 detik.

Dibawah ini disajikan data hasil eksperimen dengan pencapaian akurasi tertinggi yaitu 43,00\%. Data yang disajikan berupa persentase class recall dan class precision pada 10 kategori teks pengaduan masyarakat. Kategori-kategori yang dimaksud diantaranya prediksi Infrastruktur, prediksi Sosial Masyarakat, prediksi Kependudukan, prediksi Energi, prediksi Kesehatan, prediksi Keuangan dan Aset, prediksi Pertanian, prediksi Sektor Lain-Lain, prediksi Pendidikan, serta prediksi Kepegawaian. Data lengkapnya tercantum pada gambar 5 berikut ini. 


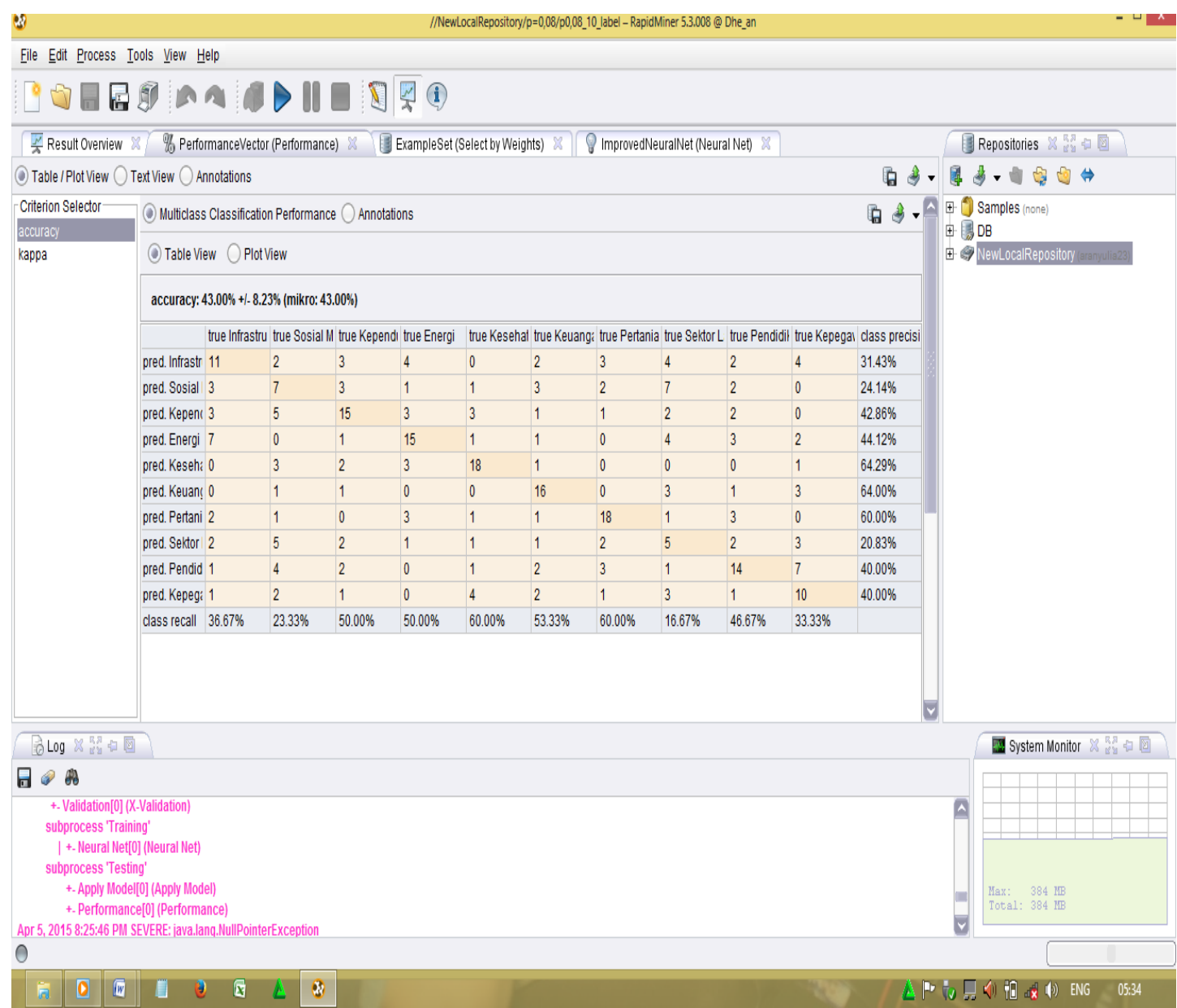

Gambar 5 : Tabel Prediksi Akurasi Pada 10 Kategori Teks Pengaduan Masyarakat 


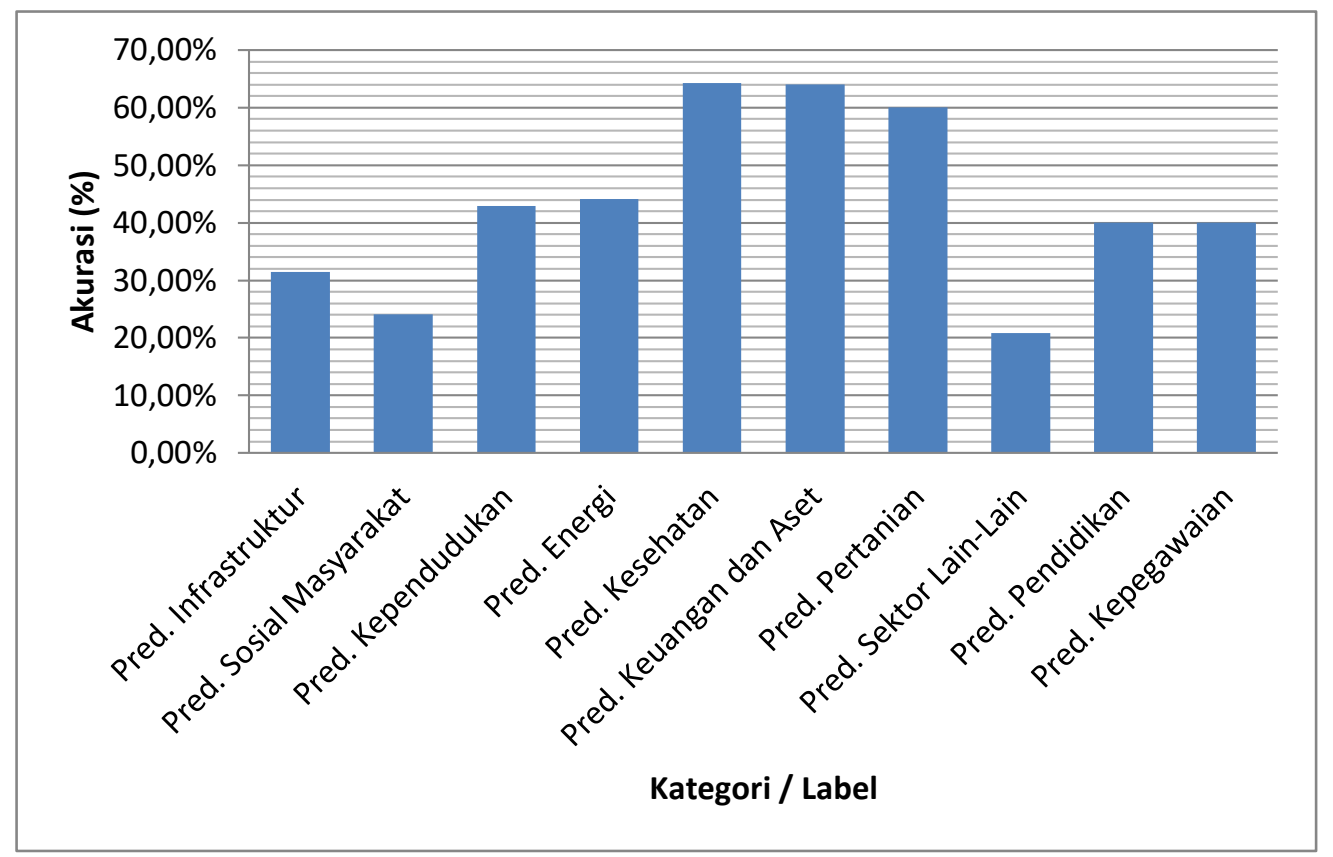

Gambar 6 : Grafik Tingkat Akurasi Tertinggi Teks Pengaduan Masyarakat Dengan P = 0,08

Pada gambar 6 di atas, disajikan dalam bentuk grafik batang untuk tingkat akurasi (class precision) pada masing-masing kategori dengan eksperimen menggunakan seleksi fitur $\mathrm{p}=0,08$. Terlihat bahwa proses seleksi fitur dengan $\mathrm{p}=0,08$ terhadap 300 teks pengaduan masyarakat menghasilkan :

1) Prediksi Infrastruktur menghasilkan $31.43 \%$.

2) Prediksi Sosial Masyarakat menghasilkan $24.14 \%$.

3) Prediksi Kependudukan menghasilkan $42.86 \%$.

4) Prediksi Energi menghasilkan $44.12 \%$.

5) Prediksi Kesehatan menghasilkan $64.29 \%$.

6) Prediksi Keuangan dan Aset menghasilkan $64.00 \%$.

7) Prediksi Pertanian menghasilkan $60.00 \%$.

8) Prediksi Sektor Lain-Lain menghasilkan $20.83 \%$.

9) Prediksi Pendidikan menghasilkan $40.00 \%$

10) Prediksi Kepegawaian menghasilkan $40.00 \%$. 
Dari semua hasil di atas, yang paling besar ialah prediksi Kesehatan yaitu menghasilkan $64.29 \%$.

Perhitungan untuk Confusion Matrix :

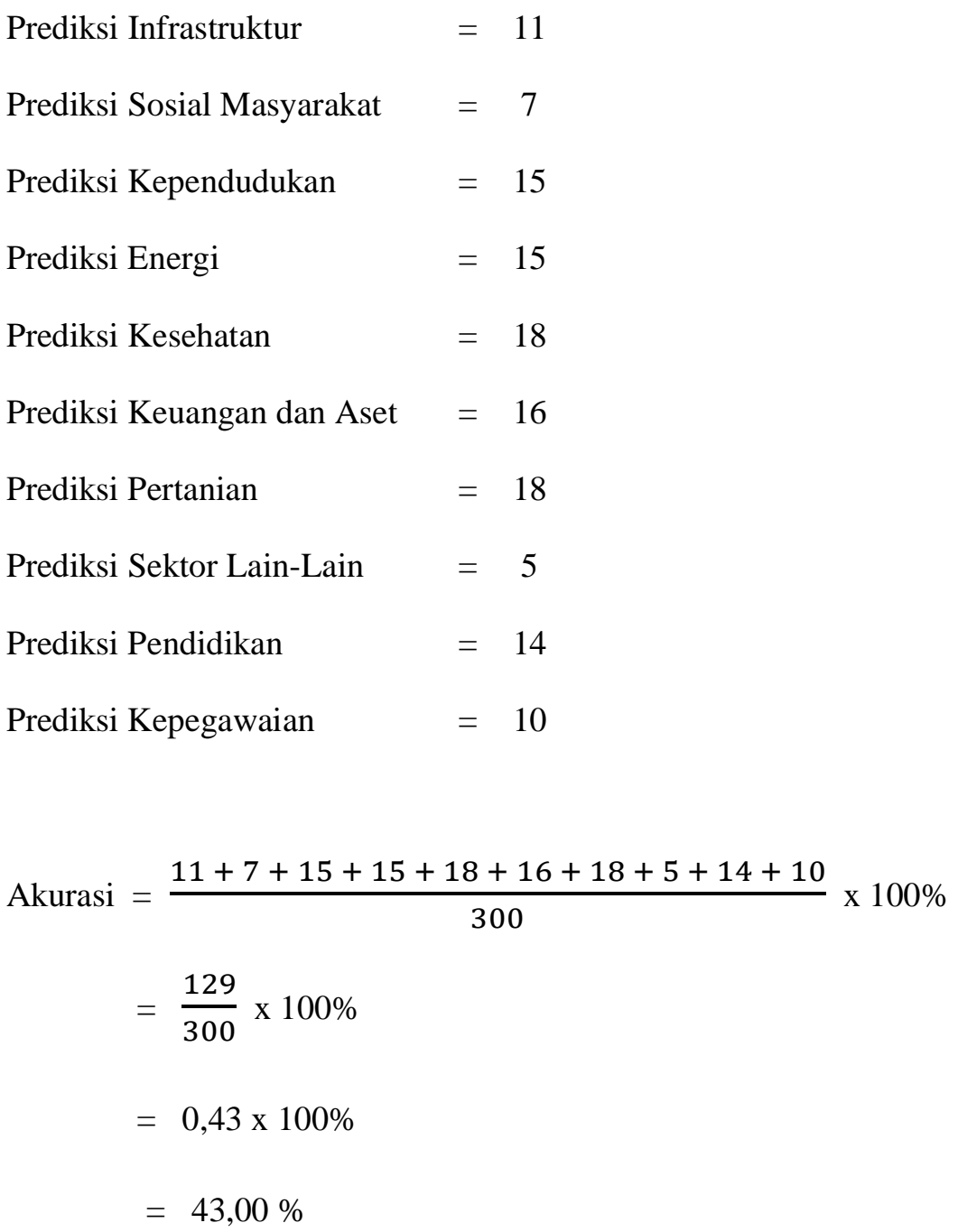

\section{Kesimpulan}

Dari hasil eksperimen, penulis memakai jumlah label yang berbeda mulai dari 4 sampai dengan 10 label dalam eksperimen pada tools rapid miner. Hasilnya dapat diketahui bahwa semakin banyak label yang digunakan dan semakin tinggi nilai $\mathrm{P}$ (seleksi fitur) dalam eksperimen, maka cenderung semakin lama waktu yang dibutuhkan dalam melakukan 
klasifikasi teks pengaduan masyarakat ini serta nilai akurasi yang dihasilkan pun cenderung semakin kecil.

Pada hasil eksperimen dengan 10 label, nilai akurasi tertinggi dihasilkan oleh proses seleksi fitur dengan $\mathrm{p}=0,08$ yaitu sebesar $43,00 \%$ dalam jangka waktu 03 jam 45 menit 14 detik. Dari hasil tersebut, yang paling besar ialah pada prediksi Kesehatan menghasilkan $64.29 \%$.

Tingkat akurasi yang dihasilkan oleh algoritma Neural Network dalam penelitian ini yaitu sebesar 43,00\% masih tergolong rendah dan waktunya relatif lama, oleh karena itu perlu dilakukan lagi pengujian dengan algoritma lain terhadap data teks pengaduan masyarakat yang sama seperti pada penelitian ini.

\section{Referensi}

Samodra J., Sumpeno S., and Hariadi M., "Klasifikasi Dokumen Teks Berbahasa Indonesia Dengan Menggunakan Naive Bayes," in Seminar Nasional Electrical, Informatics and It's Educations, Surabaya, 2009, pp. 1-4.

[2] Hamzah A., "Klasifikasi Teks Dengan Naive Bayes Classifier (NBC) Untuk Pengelompokan Teks Berita Dan Abstract Akademis," in Seminar Nasional Aplikasi Sains \& Teknologi (SNAST) Periode III, Yogyakarta, 2012, pp. 1-9.

[3] Puspaningrum E.Y. and Syidada S., "Reduksi Fitur Untuk Kategorisasi Text Dengan Klasifikasi Menggunakan Neural Network," Universitas Wijaya Kusuma, Surabaya, Thesis 2010.

[4] Saraswati N.W.S., "Text Mining Dengan Metode Naive Bayes Classifier Dan Support Vector Machines Untuk Sentiment Analysis," Universitas Udayana, Denpasar, Thesis 2011.

[5] Umran M. and Abidin T.F., "Pengelompokan Dokumen Menggunakan K-Means Dan Singular Value Decomposition : Studi Kasus Menggunakan Data Blog," Universitas Syiah Kuala, Banda Aceh, Thesis 2009.

[6] Ramadan R, "Penerapan Pohon Untuk Klasifikasi Teks Berbahasa Inggris," Institut Teknologi Bandung, Bandung, Thesis 2010.

[7] Mitra M., Introduction To Text Mining, Kolkata : Indian Statistical Institute, 2008.

[8] Gorunescu, Data Mining : Concept, Models, And Techniques, 12th ed., Gorunescu, Ed. Craiova, Romania: Springer, 2011. 
[9] Hearst M.A., "Untangling Text Data Mining," in Proceedings of ACL'99 : the 37th Annual Meeting of the Association for Computational Linguistics, California, 2006.

[10] Risaldi M., "Klasifikasi Kualitas Kayu Kelapa Menggunakan Algoritma Neural Network Backpropagation," Universitas Dian Nuswantoro, Semarang, Thesis 2013.

[11] Setiawan A., "Evaluasi Pemakaian Fiture Selection Pada Klasifikasi Kalimat Soal Kognitif Blooms," Universitas Dian Nuswantoro, Semarang, Thesis 2013.

[12] Arifin A.D., I. Arieshanti, and A.Z. Arifin, "Implementasi Algoritma K-Nearest Neighbour Yang Berdasarkan One pass Clustering Untuk Kategorisasi Teks," Institut Teknologi Sepuluh November, Surabaya, Thesis 2011.

[13] Supriyadi, "Penerapan Neural Network Untuk Prediksi Penyakit Kanker Payudara," Universitas Dian Nuswantoro, Semarang, Thesis 2013.

[14] Chandra T., "Metode Pembobotan Statistical Concept Based Untuk Klastering Dan Kategorisasi Dokumen Berbahasa Indonesia," Institut Teknologi Telkom, Bandung, Tugas Akhir 2009.

[15] Larose D.T., Discovering Knowledge In Database. New Jersey, Amerika Serikat: John Willey \& Sons Inc, 2008.

[16] Wu X and Kumar V, "Top 10 Algorithms In Data Mining," vol. I, no. 14, pp. 1-37, Desember 2008.

[17] Ghosh S., Roy S., and Bandyopadhyay S.K., "A Tutorial Review on Text Mining Algorithms," International Journal of Advanced Research in Computer and Communication Engineering, vol. 1, no. 4, pp. 1-11, June 2012.

[18] Khan A., Baharudin B., and Khan K., "A Review of Machine Learning Algorithms for Text-Documents Classification," Journal of Advances in Information Technology, vol. 1, no. 1, pp. 1-17, February 2010.

[19] Ikonomakis M., Kotsiantis S, and Tampakas V., "Text Classification Using Machine Learning Techniques," WSEAS Transactions on Computers, vol. 4, no. 8, pp. 1-9, August 2005 .

[20] Dalal M.K. and Zaveri M.A., "Automatic Text Classification : A Technical Review," International Journal of Computer Applications (0975 - 8887), vol. 28, no. 2, pp. 1-4, August 2011.

[21] Radovanovic M and Ivanovic M, "Text Mining : Approaches And Applications," International Journal of Novi Sad J. Math, vol. 38, no. 3, pp. 227-234, 2008. 
[22] Kurniawan A, "Peramalan Awal Musim Hujan Menggunakan Jaringan Syaraf Tiruan Backpropagation Lavenbergh-Marquardt," Institut Pertanian Bogor, Bogor, Tugas Akhir 2012.

[23] Krizhevsky A., Sutskever I, and Hinton G.E., "ImageNet Classification with Deep Convolutional Neural Network," University of Toronto, Canada, Paper 2012.

[24] Wermter S, "Neural Network Agents for Learning Semantic Text Classification," University of Sunderland, Singapore, Paper 2008.

[25] Lam S.L.Y. and Lee D.L., "Feature Reduction for Neural Network Based Text Categorization," in Proceedings of the Sixth International Conference on Database Systems for Advanced Application, Taiwan, 2008, pp. 195-202.

[26] Remeikis N., Skucas I., and Melninkaite V., "Text Categorization Using Neural Networks Intialized with Decision Trees," Informatica, vol. 15, no. 4, pp. 551-564, September 2004.

[27] Kusrini and Luthfi E.T., Algoritma Data Mining. Yogyakarta, Indonesia: Andi Publishing, 2009.

[28] Ridwan, Metode dan Teknik Menyusun Tesis. Bandung, Indonesia: Alfabeta, 2008. 